Article

\title{
Knockout of Arabidopsis thaliana VEP1, Encoding a PRISE (Progesterone 5 $\beta$-Reductase/Iridoid Synthase-Like Enzyme), Leads to Metabolic Changes in Response to Exogenous Methyl Vinyl Ketone (MVK)
}

\author{
Jan Klein ${ }^{1}$, Mona Ernst ${ }^{2}$, Alexander Christmann ${ }^{3}$, Marina Tropper ${ }^{2}{ }^{(0}$, Tim Leykauf ${ }^{2}\left(\mathbb{O}\right.$, Wolfgang Kreis $^{2}(\mathbb{D}$ \\ and Jennifer Munkert ${ }^{2, *}$ \\ 1 Department of Plant Physiology, Matthias-Schleiden-Institute for Genetics, Bioinformatics and Molecular \\ Botany, University of Jena, 07743 Jena, Germany; jan.klein@uni-jena.de \\ 2 Department of Biology, University of Erlangen-Nuremberg, 91058 Erlangen, Germany; \\ mona.ernst@gmx.de (M.E.); marina.tropper@fau.de (M.T.); tim.leykauf@fau.de (T.L.); \\ wolfgang.kreis@fau.de (W.K.) \\ 3 Chair of Botany, TUM School of Life Sciences Weihenstephan, Technical University of Munich, \\ 85354 Freising, Germany; alexander.christmann@tum.de \\ * Correspondence: jennifer.munkert@fau.de; Tel.: +49-91318528251
}

check for updates

Citation: Klein, J.; Ernst, M.; Christmann, A.; Tropper, M.; Leykauf, T.; Kreis, W.; Munkert, J. Knockout of Arabidopsis thaliana VEP1, Encoding a PRISE

(Progesterone 5 $\beta$-Reductase/Iridoid Synthase-Like Enzyme), Leads to Metabolic Changes in Response to Exogenous Methyl Vinyl Ketone (MVK). Metabolites 2022, 12, 11. https://doi.org/10.3390/ metabo12010011

Academic Editors: David Gagneul and Jose Lorenzo Rodriguez

Received: 29 September 2021 Accepted: 19 December 2021 Published: 23 December 2021

Publisher's Note: MDPI stays neutral with regard to jurisdictional claims in published maps and institutional affiliations.

Copyright: (C) 2021 by the authors. Licensee MDPI, Basel, Switzerland. This article is an open access article distributed under the terms and conditions of the Creative Commons Attribution (CC BY) license (https:// creativecommons.org/licenses/by/ $4.0 /)$.

\begin{abstract}
Small or specialized natural products (SNAPs) produced by plants vary greatly in structure and function, leading to selective advantages during evolution. With a limited number of genes available, a high promiscuity of the enzymes involved allows the generation of a broad range of SNAPs in complex metabolic networks. Comparative metabolic studies may help to understand why — or why not—certain SNAPs are produced in plants. Here, we used the wound-induced, vein patterning regulating VEP1 (AtStR1, At4g24220) and its paralogue gene on locus At5g58750 (AtStR2) from Arabidopsis to study this issue. The enzymes encoded by VEP1-like genes were clustered under the term PRISEs (progesterone $5 \beta$-reductase/iridoid synthase-like enzymes) as it was previously demonstrated that they are involved in cardenolide and/or iridoid biosynthesis in other plants. In order to further understand the general role of PRISEs and to detect additional more "accidental" roles we herein characterized $A$. thaliana steroid reductase 1 (AtStR1) and compared it to $A$. thaliana steroid reductase 2 (AtStR2). We used A. thaliana Col-0 wildtype plants as well as VEP1 knockout mutants and VEP1 knockout mutants overexpressing either AtStR1 or AtStR2 to investigate the effects on vein patterning and on the stress response after treatment with methyl vinyl ketone (MVK). Our results added evidence to the assumption that $A t S t R 1$ and AtStR2, as well as PRISEs in general, play specific roles in stress and defense situations and may be responsible for sudden metabolic shifts.
\end{abstract}

Keywords: Arabidopsis thaliana; steroid reductase; reactive electrophile species; specialized metabolism

\section{Introduction}

Specialized metabolism, sometimes still termed "secondary metabolism", has been studied extensively in plants and microorganisms. In the twentieth century, the vast chemical diversity of the natural products formed by plants attracted organic chemists even more than plant biologists. A lot of the complex natural products appearing in certain taxa during different developmental stages were labelled as "secondary" metabolites because a fundamental role in cell metabolism and growth was not seen. Today, several small (or specialized) natural plant products (SNAPs), such as jasmonates, brassinosteroids, and strigolactones have lost their stigma of being secondary metabolites. They are now regarded as important regulatory elements of plant development and growth. In some instances, it is difficult to determine which metabolite is "secondary" and which is "primary", particularly when they share a common biosynthetic route and the same structural scaffold. Examples are psilocybin (a toxic alkaloid) and indole-3-acetic acid (a phytohormone), both derived 
from tryptophan, or $\beta$-sitosterol (a regulator of membrane fluidity in plants) and digitonin (a toxic saponin) both formed via the mevalonic acid pathway. A "secondary" pathway leading to just a single specific natural product therefore does not seem very probable. SNAP formation depends on the availability of suitable substrates and enzymes able to modify them. A relaxed substrate specificity of many enzymes enhances a plant's options to develop complex metabolic grids, because a limited number of genes is available in a plant's genome to encode the respective enzymes. This is also the basis for substrateenzyme coevolution, which has been demonstrated as the fundamental principle leading to the formation of SNAPs [1,2]. Ecological and environmental factors might lock in a certain SNAP profile for a time and allow the taking of metabolic snapshots using modern tools of comparative metabolism, such as metabolomics. Comparative metabolism studies help with understanding and predicting the metabolic fate of pharmaceuticals and other xenobiotics in animals but may also do so in plants [3]. For example, they are advised to be conducted in pesticide risk assessment [4]. Other than studies related to the metabolism of xenobiotics, comparison of genes, enzymes and metabolites of plants that either do or do not produce a certain group of SNAPs provides a new aspect for comparative metabolism. This approach may help to understand the more general roles of enzymes assumed to be mainly responsible for the production and accumulation of certain natural compounds.

The Arabidopsis thaliana gene VEP1 (At4g24220) [5], also described as AWI 31 [6], is ideal to use in comparative metabolism studies. Wounding or environmental stressors enhanced VEP1 expression in A. thaliana [6]. Gene knockouts developed a phenotype with altered vein patterning [5]. Based on in silico analyses only one other locus (At5g58750) was identified within the genome of $A$. thaliana encoding a related protein [7]. The enzymes encoded by At4g24220 and At5g58750 were termed AtStR1 (A. thaliana steroid reductase 1) and AtStR2 (A. thaliana steroid reductase 2), because they reduced the double bond of $\triangle 4,5$-steroids and other $\alpha, \beta$-unsaturated ketones [8,9]. All enzymes encoded by VEP1-like genes were grouped under the name PRISEs (progesterone $5 \beta$-reductase/ iridoid synthaselike enzymes) [10]. In the plant progesterone $5 \beta$-reductase family, iridoid synthase activity was commonly detected [7].

PRISEs came into focus in specialized plant metabolism because they act as progesterone $5 \beta$-reductases in $5 \beta$-cardenolide biosynthesis [11-14] and iridoid synthases in iridoid biosynthesis [7,15]. RNAi-mediated gene knockdown of PRISEs led to reduced cardenolide contents in Digitalis lanata [14]. The direct participation of PRISEs in iridoid biosynthesis was demonstrated in virus-induced gene silencing (VIGS) experiments using Catharanthus roseus [15]. It was only recently proposed that PRISEs could provide a catalytic reservoir for specialized metabolism across all land plants [16].

VEP1-like genes appeared early in plant evolution, and it was assumed that a gene transfer from $\alpha$-proteobacteria ultimately helped early plants to adapt to life on land [17]. A recent database search yielded hits for VEP1-like genes in 198 species of seed plants, most of them containing neither cardenolides nor iridoids, including $A$. thaliana [9]. However, the VEP1-encoded AtStR1 converted progesterone, a precursor of cardenolides, 20 times more efficiently than the corresponding Digitalis lanata enzyme [8] and it converted other small molecules even more efficiently than progesterone [18,19], and furthermore iridoid precursors were also accepted as substrates [7,9].

PRISEs can detoxify reactive electrophile species (RES), such as methyl vinyl ketone (MVK) (Figure 1), a product of trienoic fatty acid peroxidation [20], very efficiently [7,9]. $V E P 1$ gene products may have enhanced the pathogenicity of $\alpha$-proteobacteria by interrupting defense-related signal cascades involving RES. This may have assisted the plants conquering land to survive in an oxygen-containing atmosphere that promoted lipid peroxidation without a pathogen attack [17]. 


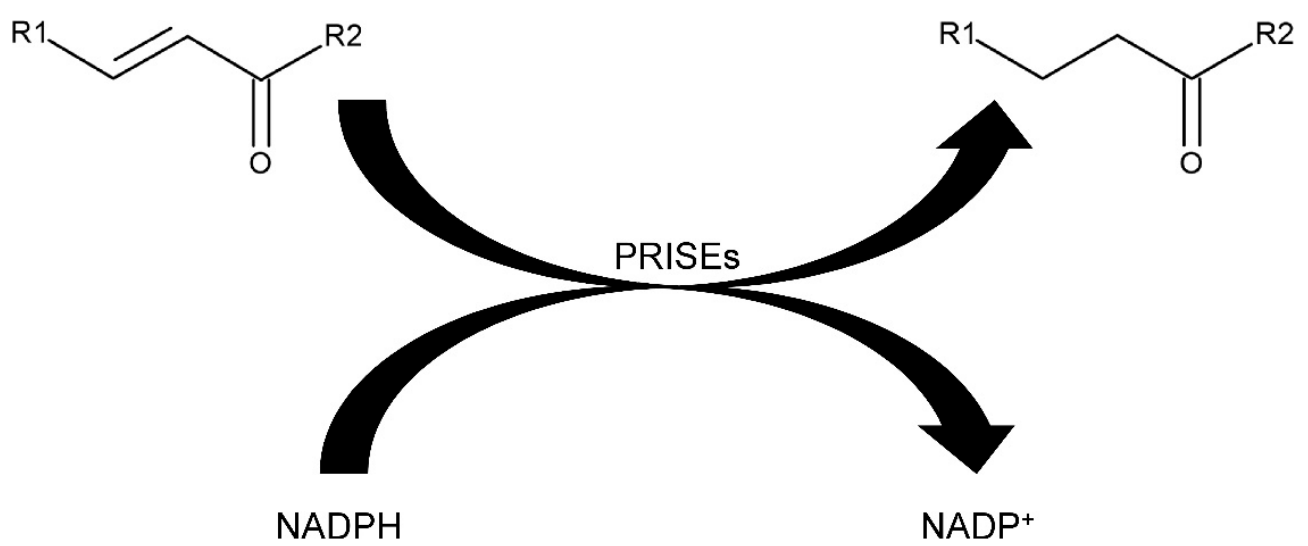

Figure 1. Detoxification of reactive electrophile species (RES) by PRISEs. $\mathrm{R}_{1}=\mathrm{R}_{2}=\mathrm{CH}_{3}$ : methyl vinyl ketone (3-buten-2-one) is converted to 2-butanone.

MVK is a powerful inducer of defense-related gene expression [21] and PRISEs may therefore modify stress responses through metabolizing MVK and related compounds. Consequently, a more general physiological role for PRISEs has been proposed in stress responses and detoxification processes $[9,14]$.

In order to investigate the general role of PRISEs and to elucidate their "accidental" roles we characterized AtStR1 and compared it to AtStR2. We used A. thaliana Col-0 wildtype (wt) plants as well as AtStR1 knockout mutants (AtStR1-) and knockout mutants overexpressing either AtStR1 (35S:AtStR1/AtStR1-) or AtStR2 (35S:AtStR2/AtStR1-) to investigate the effects of MVK treatment.

\section{Results and Discussion}

\subsection{Characterization of AtStR2}

AtStR2 is encoded by locus At5g58750. An appropriate cDNA was deduced and cloned into a pDEST17 expression vector and then functionally expressed in E. coli. The recombinant enzyme was termed $\mathrm{r} A t S t R 2$. It was purified (Figure S1) and then used for enzyme characterization. We demonstrated that $\mathrm{r} A t \mathrm{StR} 2$ converted progesterone enantioselectively into $5 \beta$-pregnane-3,20-dione (Figure S2). Progesterone was converted equally well by $\mathrm{r} A t \mathrm{StR} 2$ and $\mathrm{r} A t \mathrm{StR} 1$, but AtStR1 converted MVK much better than $\mathrm{r} A t \mathrm{StR} 2$ (Table 1). AtStR1 and AtStR2 were aligned together with other members of the PRISE family using ClustalW [22] and all PRISE motifs described by [23,24] could be identified (Figure 2).

Motifs I to III are typically present in all $\mathrm{NADP}^{+}$-dependent SDRs, the protein family to which the PRISEs belong. NADPH ${ }_{2}$ but not $\mathrm{NADH}_{2}$ was accepted as a cosubstrate by AtStR2 (Table 1). In all PRISEs investigated so far, $\mathrm{NADPH}_{2}$ was the preferred cosubstrate. Cosubstrate specificity in AtSt $5 \beta R$ muteins was previously changed with limited success modifying the typical $\mathrm{NADPH}_{2}$-binding motif GVARR [25].

AtStR2 shares $92 \%$ amino acid identity with a PRISE from Erysimum crepidifolium (AGT29343.1). This high interspecific similarity and the much lower intraspecific similarity (less than $40 \%$ identity between AtStR1 and AtStR2, as well as EcP5 $\beta R 1$ and EcP5 $\beta R 2$, respectively) led to the assumption that at least two clusters (cluster I and cluster II) of PRISEs needed to be differentiated [7]. Only two PRISE genes were identified in the genome of $A$. thaliana, whereas up to seven VEP1-like genes were reported in other plant genomes [9]. Examples of cluster I and cluster II PRISEs are shown in Table 1. When the substrate spectra of AtStR1 and other cluster I PRISEs were studied, it was demonstrated that these enzymes converted small RES more efficiently $[7,9,19]$. Methyl vinyl ketone (MVK) belongs to this group of compounds. When calculating the progesterone/MVK quotient $\left(\mathrm{Q}_{\mathrm{P} / \mathrm{M}}\right)$ of the catalytic efficiencies shown in Table 1, it became obvious that PRISEs of cluster I usually prefer MVK over progesterone as a substrate, indicated by a smaller 
$\mathrm{Q}_{\mathrm{P} / \mathrm{M}}\left(\right.$ for example, $\mathrm{Q}_{\mathrm{P} / \mathrm{M}}$ AtStR $1=0.29$ but $\mathrm{Q}_{\mathrm{P} / \mathrm{M}}$ AtStR2 $=14.20$ and $\mathrm{Q}_{\mathrm{P} / \mathrm{M}} E c \mathrm{P} 5 \beta \mathrm{R} 1=0.01$ but $\left.\mathrm{Q}_{\mathrm{P} / \mathrm{M}} E c \mathrm{P} 5 \beta \mathrm{R} 2=2.25\right)$.

\begin{tabular}{|c|c|c|}
\hline & $\begin{array}{l}\text { Motif I } \\
\text { GXTGIXG }\end{array}$ & \\
\hline AtstR2 & -----MGSEN---GSLMRRNEVDENVALI I FVTGLVGREIVRTLLMSK---P & 41 \\
\hline ECP5BR2 & 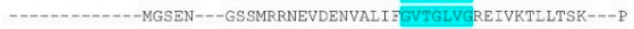 & 41 \\
\hline CXP5BR6 & MAEENSNESVALIV GVTGMVGVALAEALKKPAVLGG & 36 \\
\hline D1P5BR2 & MYTDTTTWWYKRS I GDI KQKNVETNGVALNYKSVALIVGVTGIAGSSGLAETLSMS DT PGG & 60 \\
\hline ALStR1 & $-----M S W W$ AGAIGAAKKK-LDEDEPSQSEESVALI I GVTG IVGNSLAE ILPLS DT PGG & 54 \\
\hline ECP5BR1 & ---- MSWWGAGAIGAAKKK-LDDDEPSQSYESVALIIGVIGIVGNSLAEILPLSDTPGG & 54 \\
\hline DIP5BR1 & $----M S W W W A G A I G A A K K R-L E E D D A Q P K H S S V A L I V G V T G I I G N S L A E I L P L A D T$ PGG & 54 \\
\hline \multirow[t]{3}{*}{ CrP5 $\beta$ R2 } & $----M S W W W A G A I G V A K R K-L D D F D A P F K Y Q S V G L I L G V T G I V G N S L A E I L P L S D T P G G$ & 54 \\
\hline & 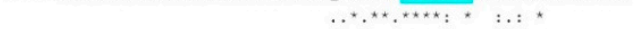 & \\
\hline & $\begin{array}{l}\text { Motif IV } \\
\text { DhrHhFYVPWX }\end{array}$ & \\
\hline AtStR2 & GWRIYGVARNPEIN--SMTKMYNFISCDLLNASETKQRLSPLQDIVSHVFWVTWSGEFPL & 99 \\
\hline ECP5BR2 & RWKIYGVARNPEIN--TMAKMYSFISCDLLNASETKQKLSPLQDIVSHVEWVTWSGEYPL & 99 \\
\hline CXP5BR6 & PWKVYGVARRPLPTWF PSSLIDNFLIFDALNTEETHQKLSPFSSEITHVFWVALQIGE-- & 94 \\
\hline D1P5BR2 & PWKVYGVARRPCPEWLAKLHV-SYIQCDIGSTDDTSAKLSPLS-DITHIFYVSWIIG---- & 114 \\
\hline AtStR1 & PWKVYGVARRPRPTWNADHPI-DYIOCDVSLAEDTRSKLSPLT-DVTHVFYVTWINRE-- & 110 \\
\hline ECP5BR1 & PWKVYGVARRPRPSWNADHPI-DYIQCDVSNAEDARSKLSPLT-DVTHVEYVTWTKRE-- & 110 \\
\hline DIP5ßR1 & PWKVYGVARRTRPAWHEDNPI-NYVQCDISLIPDSQAKLSPLT-DVTHVFYVTWANRS-- & 110 \\
\hline \multirow[t]{3}{*}{$C_{r} \mathrm{P} 5 \mathrm{BR} 2$} & PWKVYGVARRPRPSWNADHPV-EYIQCDISDPEDAQSMLSKLT-DVTHVFYVTWÄSKS-- & 110 \\
\hline & 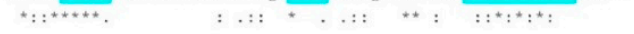 & \\
\hline & $\begin{array}{l}\text { Motif } V \\
\text { TGXKHYXGP }\end{array}$ & \\
\hline AtStR2 & DTDECCVQNKTMIMNALDAILPN-AKRLKHFSLQTGMKHYVSIVEET-MARGEGSSLYYY & 157 \\
\hline ECP5BR2 & DTDECCVQNKTMITNALDAILPN-AKRLKHFSLOGGMKYVSIVEET-LSHGEGSSLCYY & 157 \\
\hline CrP5BR6 & NEGININLNSTMLKNVLNSLRNCSNSKLKHVT LQTGTKQYMGPIFDPILSDKLI PHEPPF & 154 \\
\hline DIP5BR2 & --SEDCDKNAIMFKNILDSVI PN-APNLKHISLQGIKHYWGMVDE-MDITNVSHDCPE & 170 \\
\hline AtStR1 & SESENCEANGSMLRNVLQAII PY-APNLRHVCLQTGTKHYLG FT-N-VDG--PRHDPPF & 165 \\
\hline$E C P 5 \beta R 1$ & SESENCEANGSMIRNVLQAIVPH-APNLRHICLIGTKHYLGFTS-N-LDG--PRHDPPF & 165 \\
\hline DIP5 $\beta \mathrm{R} 1$ & TEQENCEANSKMFRNVLDAVIPN-CPNLKHISLQTGRHYMGPFE-S-YGKIE-SHDPPY & 166 \\
\hline \multirow[t]{3}{*}{ CrP5BR2 } & TEVENCEVNSKMFRNVLNAIIPN-CPNLQHICLOTGLKHYLGPFE-L-FGKAAVAHEPPF & 167 \\
\hline & 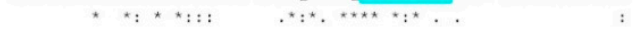 & \\
\hline & $\begin{array}{cc}\text { Motif VI } & \text { Motif VII } \\
\text { NEYYXXED } & \text { WSVHRP }\end{array}$ & \\
\hline AtStR2 & SEECPRKSSGKNFYYVLEDLLKEKITR--SSVWWSVRRGLLMGSSSRTLYNFMGSLCVY & 215 \\
\hline ECP5BR2 & SEECPRKGSGKNEYYVLEDLLKERISG--SSVVWSVQRPGLLIMGSSSRTLYNFMGSLCVY & 215 \\
\hline CrP5BR6 & REDYPRI-PF PNEYYALEDI ISSYYA----HSFTYSI IHRSSSVI IGVSTRSLYNSLLSLCVY & 209 \\
\hline D1P5BR2 & NEYMPRL-RQPEYSNLEDLIYEACRTQNGALIWTVHR ALIFGFSPCSLMNIVATLSVY & 229 \\
\hline AtStR1 & TEDMPRL-QIQ NFYYTQEDILFEIKKIE-TVTWSIHRPNMIFGFSPYSLMNIVGTLCVY & 223 \\
\hline V.CP5BR1 & TEDMPRL-QIQ NFYYTQEDI LFEEIKKKEI SVIWSI IRP PNTIFGFS PYSLMNIVGTLCVY & 224 \\
\hline DIP5BR1 & TEDLPRL-KYMNEYYDLEDIMLEEVEKKE-GLIWSVHRPGNI FGFS PYSMMNLVGTLCVY & 224 \\
\hline \multirow[t]{4}{*}{ CrP5ßR2 } & HEELPRL-DVPEYYTLEDILFEVVKKE-GLTSVHRPGNIFGFSPESLMNLVGTLCAY & 225 \\
\hline & 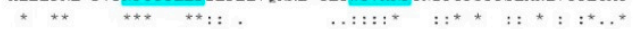 & \\
\hline & Motif VIII & \\
\hline & DXDIhAX & \\
\hline AtStR2 & GAMCKYLNIPFVFGGTRECWEESYIDGSDSNLVAEQHIFAATSGKVREKGEAFNAINGVG & 275 \\
\hline$E C P 5 \beta R 2$ & GAMCKYLNIPFVFGGTRECWEEIYIDGS DANLVAEQRIFAATSGKVRNRGEAFNAINGVG & 275 \\
\hline CrP5BR6 & ASICKYKGWEFRFPGNKYSWE-HFWDESDSRVLADQQIWASVTDK--AKNQAFNCTNGDV & 266 \\
\hline DIP5BR2 & AAICKYENKPLVYTGTQTSWN-CLVDAVPSDLLSEHLVWGAISPN--AKNQAFNINNGDV & 286 \\
\hline ALStR1 & AAICKHEGSPLLFPGSKKAWE-GFMTASPADLIAEQRIWAAVDPY--AKNEAFNCNNADI & 280 \\
\hline$E C P 5 \beta R 1$ & AAICKHEGSPLLFPGSKKAWE-GFTTASDADLIAEQRIWAAVDPY--AKNEAFNCNNADI & 281 \\
\hline DIP5BRI & AAICKHEGKVLRETGCKAAWD-GYSDCSDADLIAEHHIWAAVDPY--AKNEAFNVSNGDV & 281 \\
\hline \multirow[t]{2}{*}{ Cre5ßR2 } & AAICKHEGVPLRFPGCKEAWQ-GYSMCSDADLIAEHQIWAAVDPY--AKNEAFNVSNGDV & 282 \\
\hline & 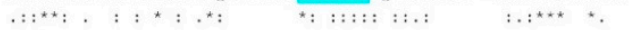 & \\
\hline & ETWKE IWPE I GKKLGVQVNETTMFDEG--FWFGREMVERKHVWDEIVVKEKLVRTEIEDL & 333 \\
\hline ECP5BR2 & FTWKE IWPE I GRKLGVQVNETTMFDEG--FWYGREMGERKHVWDEIVVKERLVRTEIEDL & 333 \\
\hline CrP5BR6 & FSWKSMWKLLCEIFE--LEFL-PFDEKVREDLVEFMKDKGGIWDEIVEKYGLFKTKMEEV & 323 \\
\hline DIP5BR2 & FKWKHIWKVLAEQLQLEIEFV-GYEGKEPVSLEGLMKDKDSVWDEMVEKYDLVPTKLRDI & 345 \\
\hline ALStR1 & FKWKHLWKILAEQFG--IEEY-GFEEGKNLGLVEMMKGKERVWEEMVKENQIQEKKLEEV & 337 \\
\hline ECP5 5 R1 & FKWKHLWKI LAEQFG--IEEY-GFEEGKNLGLVEMMKGKERVWEEMVKENQIQEKKLEEV & 338 \\
\hline DIP5BR1 & FKWKHFWKVLAEQFG--VGCG-EYEEGVDLRLQDLMKGKEPVWEEIVRENGLTPTKLKDV & 338 \\
\hline \multirow[t]{2}{*}{ CrP5ßR2 } & FKWKHFWKVLAEQFG--AEYA-EYQ-GERLSLQELMKDKG PVWENIVRENGLVPSKLEEV & 338 \\
\hline & 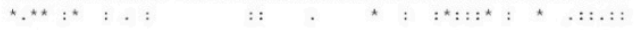 & \\
\hline & WYFLDALFRCPFKLIGKREKVDRFGFKRKYRTLDSVLYWI DVMRDEKLIPL---- & 386 \\
\hline & WFFMDVLFRCPFKLLGKRDKVDKFGFKRKYRTLDSILYWI DVMRDEKLIPL---- & 386 \\
\hline & FEALQLI LAFEFEHVCSMNKSKEFGFFGEANTLESIKFWVEKMRQMNI LSRLPDI & 380 \\
\hline D1P5 & AAFWFADVAFSIE-GAVSSMNKNKEFGEMGERDSTKSEISSVNKVRSYRFVP------ & 396 \\
\hline ntStR1 & GVWWFADVILGVE-GMIDSMNKSKEYGFLGFRNSNNSPISWIDKYKAFRIVP----- & 388 \\
\hline$\angle C P 5 \beta R 1$ & GVWWFADVI LGVE-GMI DSMNKSKEHGFLGFRNSNNSFISWI DKYKAFKIVP----- & 389 \\
\hline D1P5BR1 & GIWWFGDVILGNE-CFIDSMNKSKEHGFIGFRNSKNAZISWIDKAKAYKIVP----- & 389 \\
\hline CrP5BR2 & GVWWFADLVLSVE-CPIDSMNKSKEHGFLGERNSKNAFISWIDKAKAYKIFP----- & 389 \\
\hline
\end{tabular}

Figure 2. Amino acid alignment, performed by ClustalW, of several PRISEs. Bold: PRISEs of cluster II, namely, AtStR2 (NP_200683.1), D. lanata DlP5ßR2 (ADL28122.1), E. crepidifolium EcP5ßR2 (AGT29343.1) and C. roseus CrP5 $\beta$ R6 (AIW09148.1). Light: PRISEs of cluster I, namely, A. thaliana AtStR1 (NP_194153.1), E. crepidifolium EcP5ßR1 (ADG56544.1), D. lanata DlP5ßR1 (Q6PQJ9.1) and C. roseus CrP5 $\beta$ R2 (AIW09144.1). The motifs described by $[23,24]$ are shown in turquoise shading. The residues of the phenylalanine clamp defined by [10] are depicted in bold. Asterisk, fully conserved; colon, strongly conserved; period, weakly conserved. 
Table 1. Enzyme activity of PRISEs from A. thaliana. The kinetic constants for the cosubstrate were determined using progesterone as the substrate.

\begin{tabular}{|c|c|c|c|}
\hline Enzyme (Substrate) & $\begin{array}{c}\mathbf{K}_{\mathrm{m}} \\
(\mu \mathrm{M})\end{array}$ & $\begin{array}{c}k_{c a t} \\
\left(s^{-1}\right)\end{array}$ & $\begin{array}{l}\text { Catalytic Efficiency } \\
\qquad\left(\mathrm{s}^{-1} \mathrm{M}^{-1}\right)\end{array}$ \\
\hline \multicolumn{4}{|c|}{ rAtStR2 } \\
\hline rAtStR2 (progesterone) & 64.7 & 0.15 & 2314 \\
\hline rAtStR2 (MVK) & 157.5 & 0.03 & 163 \\
\hline $\mathrm{r} A t \mathrm{StR} 2\left(\mathrm{NADPH}_{2}\right)$ & 41.0 & 0.12 & 2927 \\
\hline \multicolumn{4}{|l|}{ Other PRISEs of cluster II } \\
\hline $\mathrm{rEcP5} \beta \mathrm{R} 2$ (progesterone) $^{\mathrm{a}}$ & 82 & 0.05 & 552 \\
\hline $\mathrm{rEcP5} \beta \mathrm{R} 2(\mathrm{MVK})^{\mathrm{a}}$ & 224 & 0.05 & 245 \\
\hline $\mathrm{rCrP5} \beta \mathrm{R} 6$ (progesterone) ${ }^{\mathrm{a}}$ & 75.5 & 0.40 & 5530 \\
\hline $\mathrm{rCrP} 5 \beta \mathrm{R} 6(\mathrm{MVK})^{\mathrm{a}}$ & 118 & 0.03 & 261 \\
\hline \multicolumn{4}{|c|}{ rAtStR1 and rAtSt5 $\beta R 1$ F153A_F342A } \\
\hline rAtStR1 (progesterone) ${ }^{b}$ & 124.8 & 0.28 & 2244 \\
\hline $\mathrm{r} A t \mathrm{StR} 1(\mathrm{MVK})^{\mathrm{b}}$ & 75.5 & 0.20 & 7299 \\
\hline rAtStR1_F153A_F342A (progesterone) ${ }^{\mathrm{c}}$ & 217 & 2.00 & 9218 \\
\hline rAtStR1_F153A_F342A (MVK) ${ }^{c}$ & - & n.a. & - \\
\hline \multicolumn{4}{|l|}{ Other PRISEs of cluster I } \\
\hline $\mathrm{rEcP} 5 \beta \mathrm{R} 1$ (progesterone) $^{\mathrm{b}}$ & 77 & 0.01 & 31 \\
\hline $\mathrm{rEcP5} \beta \mathrm{R} 1(\mathrm{MVK})^{\mathrm{b}}$ & 344 & 0.72 & 2143 \\
\hline $\mathrm{rCrP} 5 \beta \mathrm{R} 4$ (progesterone) $^{\mathrm{b}}$ & 153 & 0.02 & 123 \\
\hline $\mathrm{rCrP} 5 \beta \mathrm{R} 4(\mathrm{MVK})^{\mathrm{b}}$ & 123 & 0.20 & 1562 \\
\hline \multicolumn{4}{|c|}{ Other MVK-converting enzymes } \\
\hline AtAER $(\mathrm{MVK})^{\mathrm{d}}$ & 55.0 & 83.0 & $1,500,000$ \\
\hline AtAOR (MVK) $\mathrm{e}$ & 2880 & 74.0 & 25,700 \\
\hline
\end{tabular}

${ }^{\mathrm{a}}[7] ;{ }^{\mathrm{b}}[9] ;^{\mathrm{c}}[10] ;{ }^{\mathrm{d}}[26] ;{ }^{\mathrm{e}}[27]$. n.a. $=$ not accepted as substrate; $n>3$.

Petersen et al. [10] generated recombinant AtStR1 muteins that had almost or completely lost their capacity to convert MVK and small cyclic 1,4-enones, such as cyclocexen-1-one. These muteins preferred larger substrates such as progesterone, a precursor of $5 \beta$-cardenolides (Table 1) and 8-oxogeranial, a precursor of iridoids instead [10].

This was achieved by the removal of the phenylalanines forming a clamp structure at the rim of the binding pocket [9]. With the disruption of this feature, small, rather hydrophilic 1,4-enones may not be "trapped" in the binding pocket long enough to allow for the conversion $[9,10]$. Since the phenylalanine clamp is highly conserved and found in most of the class I PRISEs described so far, it seems as if these enzymes were not optimized for larger molecules such as progesterone [9].

To analyze this in more detail, we here modeled AtStR2 on the crystal structure of AtStR1 (PDB entry 6el3.1.A) cocrystallized with $\mathrm{NADP}^{+}$[9], which is available in the RSCB protein data bank [28]. The model was created using Swissmodel [29] and progesterone was docked into the active site (Figure 3) with AutoDock Vina [30]. The results were visualized in USCF Chimera [31] and demonstrated a different fit of progesterone in the active site of AtStR1 and AtStR2, respectively. 
a

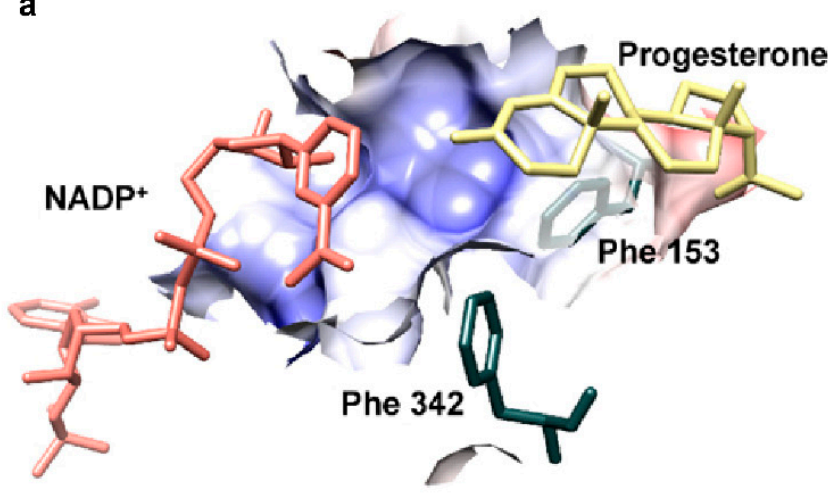

b

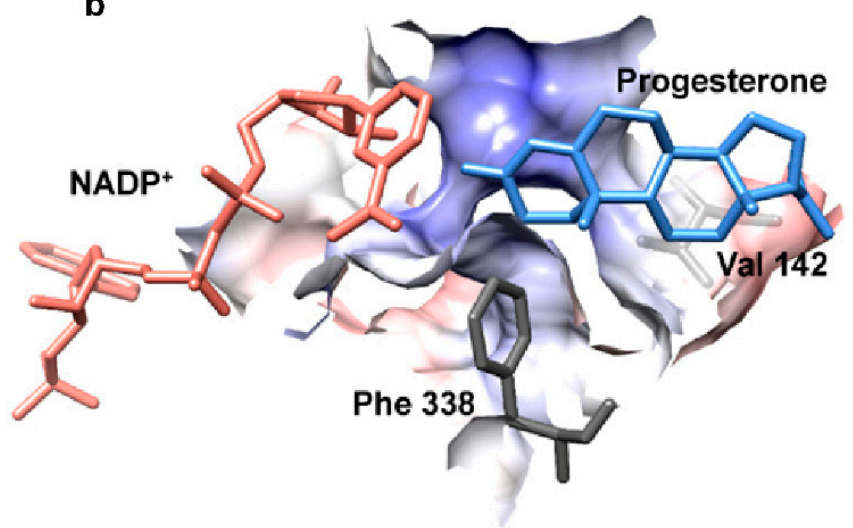

Figure 3. Docking of progesterone into the active site of AtStR1 (a) and homology-modelled AtStR2 (b). The coulombic surface is displayed for important residues in the active site according to [32]. $\mathrm{NADP}^{+}$(red), progesterone (yellow for AtStR1, blue for AtStR2) and the phenylalanine clamp residues (green for AtStR1, grey for AtStR2) are shown as stick models.

In AtStR2, as well as in other cluster II PRISEs, the phenylalanine adjacent to motif 5 was substituted for other amino acids, hence a phenylalanine clamp could not be formed. As a consequence, the active site could accommodate larger molecules such as progesterone (Figure 3).

The loss of activity regarding small molecules, which cannot be trapped in the active site has already been described [10]. Their interpretation of the important role of a phenylalanine clamp at the rim of the binding pocket is consistent with the observation that the cluster II PRISEs we analyzed here (Figure 2) lack at least one of the two phenylalanines. This explains their lower catalytic efficiency for MVK. With this in mind, the

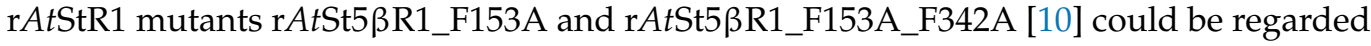
as cluster I PRISEs converted to cluster II PRISEs. The substrate preferences of $\mathrm{r} A t S t R 1$, and its mutants have already been characterized quite well $[10,18,19]$ whereas more data are still required for $\mathrm{r} A \mathrm{tStR} 2$.

Paralogues obtained after gene duplication may have been formed in metaboliteenzyme coevolution [2] towards the preference of larger molecules and the discrimination of small RES released in stress reactions. Other substrate-promiscuous enzymes such as BAHD-type malonyltransferases may also have morphed from enzymes capable of detoxifying xenobiotics to enzymes capable of malonylating 21-hydroxypregnanes, yielding precursors of butenolide ring formation in the cardenolide biosynthesis [33]. In a similar way, PRISEs may have evolved helping to establish cardenolide formation in E. crepidifolium, a close relative of $A$. thaliana.

\subsection{Expression of AtStR1 and AtStR2}

Here, we established and analyzed three systems: (i) Ath Col-0 wt (wild type plants), (ii) homozygous SALK 097798 knockout plants (AtStR1-) and (iii) SALK 097798 expressing either AtStR1 (35S:AtStR1/AtStR1-) or AtStR2 (35S:AtStR2/AtStR1-) under the control of the CaMV 35S promotor. Homozygous knockout plants were identified using primers designed by the "SALK T-DNA verification primer design".

AtStR1 was expressed in Ath Col-0 wt but not in AtStR1- mutant plants, verifying the stable knockout of AtStR1 in the homozygous plants used here (Figure 4). AtStR2 was strongly expressed in seedlings (Figure $4 \mathrm{~b}$ ) and cold-treated adult leaves (Figure S3) but poorly in adult leaves of non-stressed A. thaliana plants (Arabidosis eFP browser 2.0; Figures $4 \mathrm{a}$ and S3). Since AtStR2 is not expressed in leaves (in normal conditions), AtStR2 activity did not interfere with the determination of AtStR1 activities in the enzyme assays of leaf extracts (Figure S4). Other enzymes possibly converting progesterone to $5 \beta$-pregnane3,20-dione seemed to be inactive (Figure S4). 
a

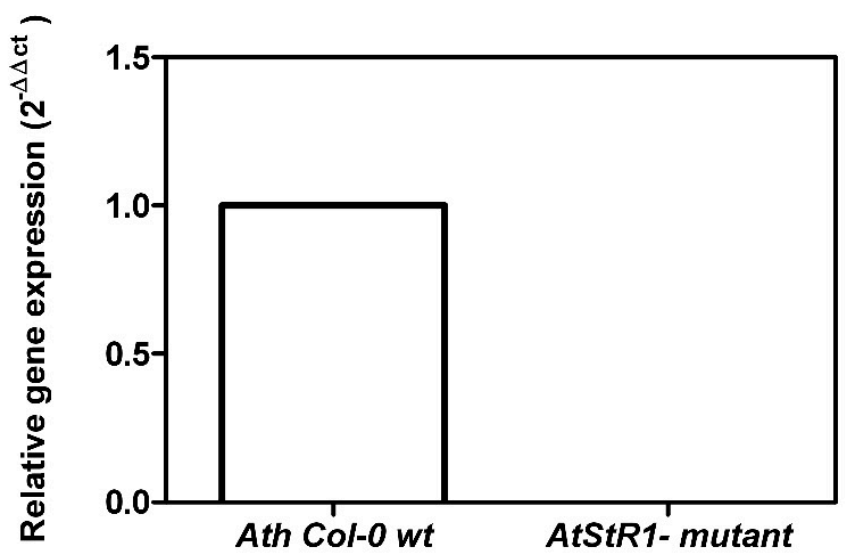

b

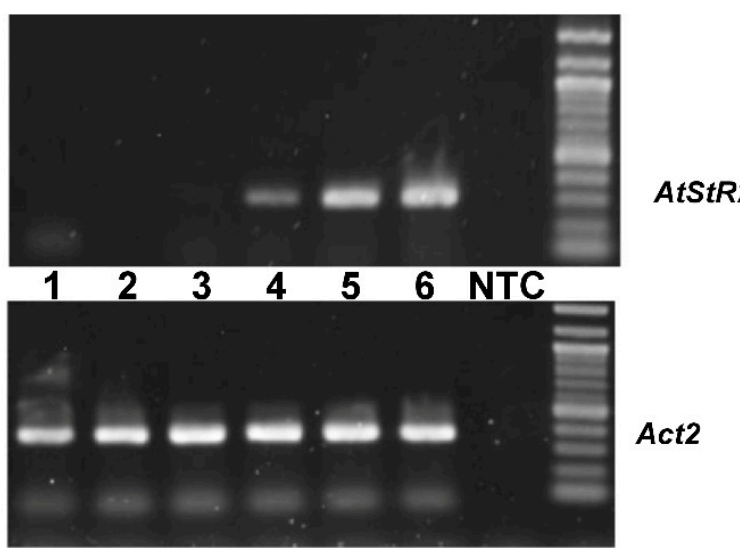

Figure 4. Expression of AtStR1 in Ath Col-0 wt and AtStR1- mutant (a) and expression of AtStR2 in adult plant leaves and in seedlings (b). (a) AtStR1 is expressed in Ath Col-0 wt but not in AtStR1- mutant (Salk 097798). (b) AtStR2 is strongly expressed in seedlings (4/5/6) but poorly in leaves of adult plants $(1 / 2 / 3)$ as confirmed by normal PCR. Act 2 and $E F 1 \alpha$ were used as reference genes in a quantitative real-time PCR experiment $(n=3)$ and Act2 was used as control gene in the semiquantitative PCR. NTC = non template control.

PRISE expression of five individual transgenic lines each (35S:AtStR1/AtStR1- and 35S:AtStR2/AtStR1-) were analyzed. The two lines of each approach showing the highest expression rates were chosen for further experiments. These lines were termed 35S:AtStR1/ AtStR1-1, 35S:AtStR1/AtStR1-2, 35S:AtStR2/AtStR1-1 and 35S:AtStR2/AtStR1-2 (Figure 5).

Insertion lines in which AtStR2 on locus At5g58750 was inactivated were not available to us. Attempts to generate plants lacking the AtStR2-encoding gene using either RNAi-mediated gene knockdown or CRISPR/Cas9-mediated gene knockout have been unsuccessful. It is possible that AtStR2 might be essential for plant development and a lack of it stops seed germination or seedling development.

Progesterone 5 $\beta$-reductase activity was recovered in the 35S:AtStR1/AtStR1- as well as in 35S:AtStR2/AtStR1- lines, indicating that the respective enzymes were produced in an active form (Figure $S 4)$.

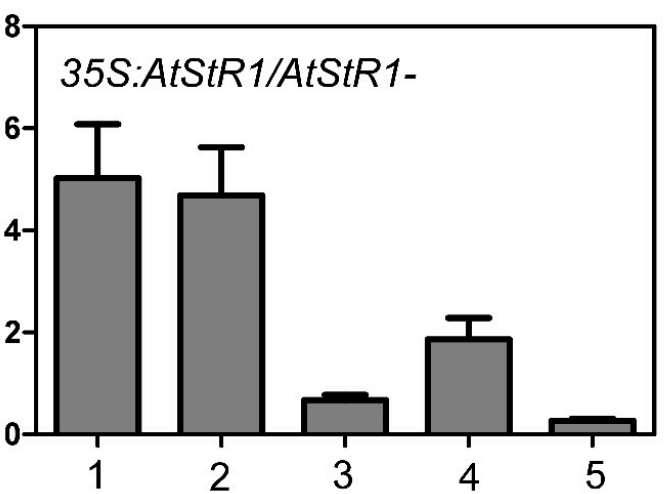

b

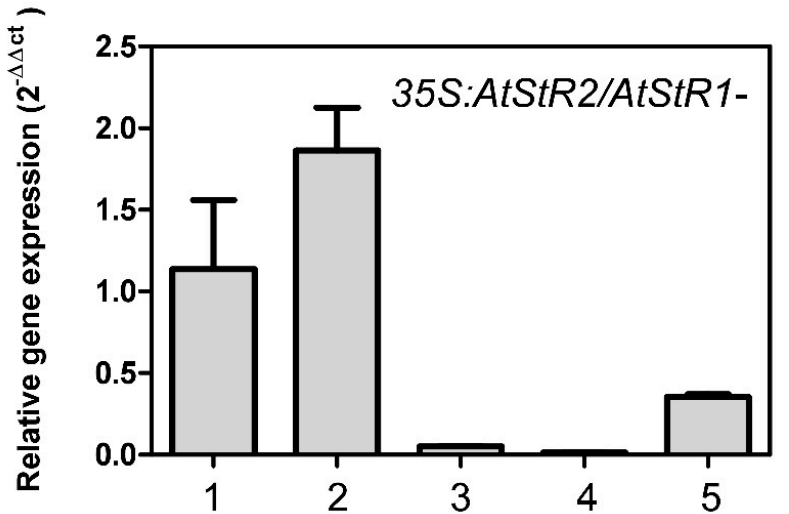

Figure 5. Expression of AtStR1 gene in transgenic 35S:AtStR1/AtStR1- (a) and expression of AtStR2 gene in 35S:AtStR2/AtStR1- mutant lines (b). mRNA values were measured by quantitative real-time PCR, quantified by $2^{-\Delta \Delta c t}$ method using $A c t 2$ and $E F 1 \alpha$ as reference genes $(n=3)$. Numbers $1-5$ indicate individual lines 35S:AtStR1/AtStR1-1-5 and 35S:AtStR2/AtStR1-1-5. 
We investigated the effects of MVK treatment on Ath Col-0 wt and mutant plants, because MVK is a powerful inducer of defense-related gene expression [21] and PRISEs could be involved in the stress response simply by metabolizing MVK itself. We analyzed surrogate parameters for the stress response, such as $\mathrm{H}_{2} \mathrm{O}_{2}$ levels and glutathione reductase (GR1) expression. Glutathione reductase (GR1) is an enzyme influencing the redox state of a cell by releasing reduced glutathione (GSH) from oxidized glutathione (GSSG) [34]. Redox states can therefore be evaluated by measuring GR1 expression [14].

AtStR2 was not induced under MVK stress and $\mathrm{r}$ AtStR2 only poorly accepted MVK (Table 1). Moreover, the redox state as estimated by GR1 expression and $\mathrm{H}_{2} \mathrm{O}_{2}$ production was not altered in AtStR1- mutants transformed with 35S:AtStR2 (Figure 6). The A. thaliana glutathione reductase gene GR1 is expressed twice as high in AtStR1- mutants than in Ath Col-0 wt. $\mathrm{H}_{2} \mathrm{O}_{2}$ levels were also higher in AtStR1- mutants than in Ath Col-0 wt (Figure 6). This indicates reduced GSH availability. The effect could be reduced to wild type levels after curing the AtStR1- mutant with 35S:AtStR1 but not with 35S:AtStR2. A disturbed redox state, indicated by a changed expression of a cytosolic glutathione reductase and increased $\mathrm{H}_{2} \mathrm{O}_{2}$ levels, was also seen in D. lanata RNAi shoot culture lines in which VEP1like genes were knocked down. In these mutants, four times higher GSH levels compared to wild type controls have been demonstrated [14].

\subsection{Roles of AtStR1 and AtStR2 in Plant Reactive Electrophilic Species (RES) Stress}

Cardenolide and/or iridoid pathways are not known to be present in A. thaliana. Iridoids are not known to occur in the Brassicaceae and only few genera, including Erysimum, accumulate cardenolides. AtStRs cannot be involved in pathways that are not existent in A. thaliana. Consequently, though capable of reducing the double bond of progesterone enantioselectively, here PRISEs simply cannot be connected to $5 \beta$-cardenolide formation. Enzymes as well as pregnane precursors may, however, be part of a "silent metabolism" in which putative intermediates and enzymes are present that have not yet been detected or are not associated with known metabolic pathways [1,35]. Studies in comparative metabolism (including metabolomics techniques) may help to better understand and evaluate these "silent" resources.

a

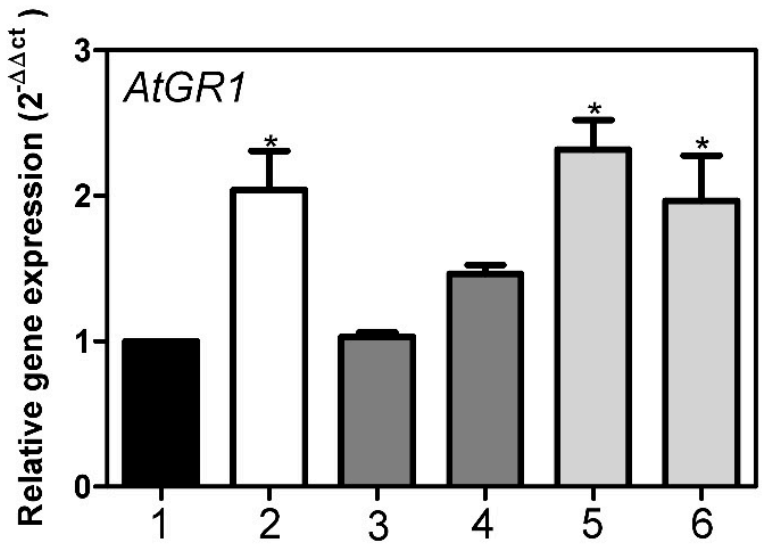

b

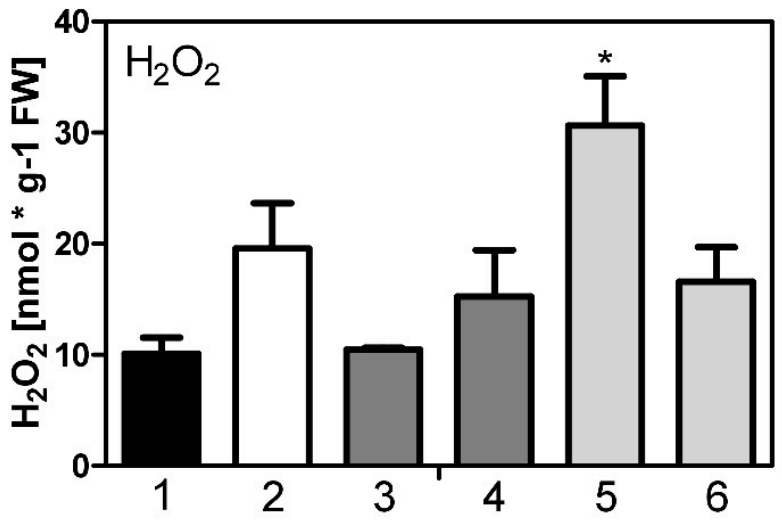

Figure 6. Expression of glutathione reductase (GR1) in leaves of $A$. thaliana Col-0 wt and mutant lines (a) and quantification of $\mathrm{H}_{2} \mathrm{O}_{2}$ levels (b) in A. thaliana Col-0 wt and mutant lines. (1) Ath Col-0 wt, (2) AtStR1-, (3) 35S:AtStR1 / AtStR1-1, (4) 35S:AtStR1/AtStR1-2, (5) 35S:AtStR2/AtStR1-1, (6) 35S:AtStR2/AtStR1-2. Mean $\pm \operatorname{STD}(n=3)$, normalized on Act2 and EF1 $\alpha\left({ }^{*}=p<0.05\right)$.

Small reactive carbonyl species, also known as reactive electrophilic species (RES) formed during stress reactions, have already been identified as putative substrates for PRISEs. Examples are small 1,4-enones such as methyl vinyl ketone (MVK) or 1-cyclohexen-2-one which are converted by AtStR1 very efficiently $[7,9,10,19]$. MVK is a product of trienoic fatty acid 
peroxidation [20]. MVK accumulates in various stress situations [10,36-38] and is partly responsible for heat stress symptoms in cyclamen [20]. It is known that MVK causes tissue damage in A. thaliana [38] and Cyclamen persicum [20] leaves. The enzymatic reduction of MVK yields methyl ethyl ketone (MEK) which is harmless to plants [38]. There are other enzymes and mechanisms known to detoxify or inactivate RES. For example, RES can be detoxified by spontaneous reaction or enzymatic conjugation with reduced glutathione (GSH) [39]. RES, specifically 1,4-enones can also be reduced by aldehyde oxidoreductases (AOR) and 2-alkenal reductases (AER). We here considered these options as alternative routes for MVK detoxification and analyzed the expression pattern of the respective $A$. thaliana genes.

$V E P 1, A E R$ and $A O R$ are differentially expressed in A. thaliana. In the absence of stress, $A E R$ is expressed only weakly, whereas $A O R$ is strongly expressed in young and VEP1 in mature leaves (Arabidopsis eFP browser 2.0). The respective enzymes differ in their substrate preferences, especially the size of potential substrates. For example, an AOR of Cucumis sativa reduced 4-hexen-3-one about 100 times more efficiently than MVK [27]. On the other hand, the AtAOR characterized in the same paper was equally active towards these two substrates. The authors discussed that AOR together with other enzymes might cooperatively detoxify reactive carbonyls. We here provide evidence that VEP1-encoded PRISEs may also be important players in this scenario.

AtAER (At5g16970) encodes a cytosolic alkenal reductase in A. thaliana. As far as the kinetic constants are concerned AtStRs and AtAER have similar $K_{\mathrm{m}}$ values but differ in their catalytic efficiency, AtAER being about 200 times more efficient than AtStR1. Expression of AtAER and AtAOR was equally high in Ath Col-0 wt and in AtStR1- mutants and could be amplified by MVK, in this way paralleling enhanced AtStR1 expression (Figure 7). Since AtAER is only weakly expressed in leaves and is enhanced moderately only under MVK stress, the strong expression of AtStR1 may lead to an amount of enzyme that can efficiently compete with AtAER for MVK detoxification. AtAOR (At1g23740), in contrast to AtAER, is strongly and constitutively expressed in the chloroplast and is assumed to be involved in the general elimination of reactive carbonyls [27]. All in all, detoxification of reactive carbonyls seems to be a more complex situation with correlating enzymes working in a group and providing a detoxifying network system. However, this issue requires further investigation. A $3 \mathrm{~h}$ exposure to MVK resulted in a fourfold increase of AtStR1 expression in Ath Col-0 wt (Figure 7). Expression stayed high even after $24 \mathrm{~h}$ of treatment (data not shown). On the other hand, AtStR2 was neither expressed in the control plants nor was its expression induced after MVK treatment, even after prolonged exposure up to $24 \mathrm{~h}$.

a

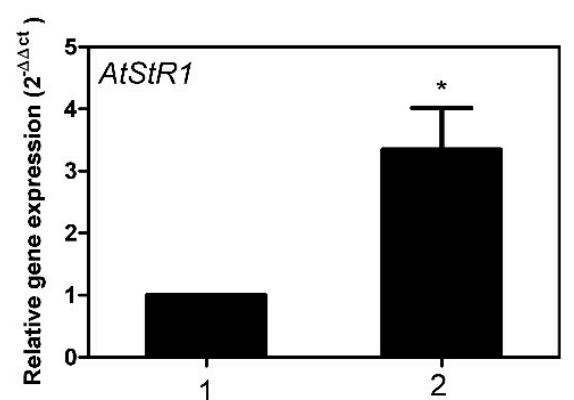

b

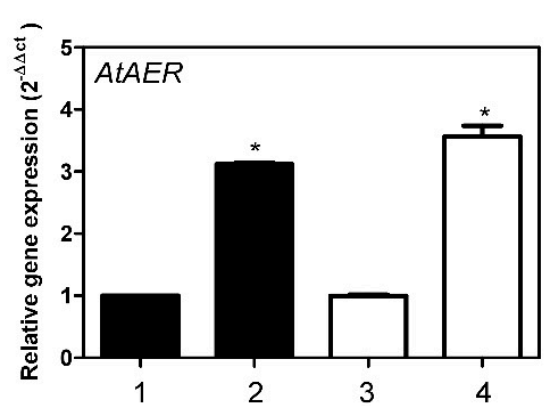

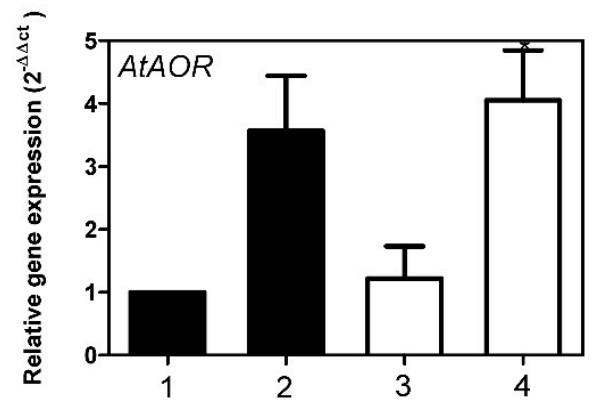

Figure 7. Expression of AtStR1 (a), AtAER (b) and AtAOR (c) in A. thaliana leaves. (1) Ath Col-0 wt, (2) Ath Col-0 wt + MVK, (3) AtStR- mutant, (4) AtStR- mutant + MVK. Mean \pm STD $(n=3)$, normalized on Act2 and EF1 $\alpha\left({ }^{*}=p<0.05\right)$.

The AtPR4 gene (also termed hel gene) has successfully been used as a surrogate to estimate MVK effects [21,40,41]. AtPR4 encodes a PR (pathogen-related) protein. PR proteins are induced in response to pathogen attacks and other stresses. When treated with MVK, AtPR4 was expressed around five times higher in AtStR1- mutants than in 
Ath Col-0 wt. This difference was taken as an indication for impaired MVK detoxification in AtStR1- mutants. Support for this conclusion was obtained from experiments with AtStR1- mutants overexpressing 35S:AtStR1, where AtPR4 expression levels were again comparable with those of Ath Col-0 wt (Figure 8). Overexpressing 35S:AtStR2 in AtStR1- mutants did not result in the attenuation of AtPR4 expression. This showed that mainly AtStR1 but not AtStR2 is involved in MVK detoxification.

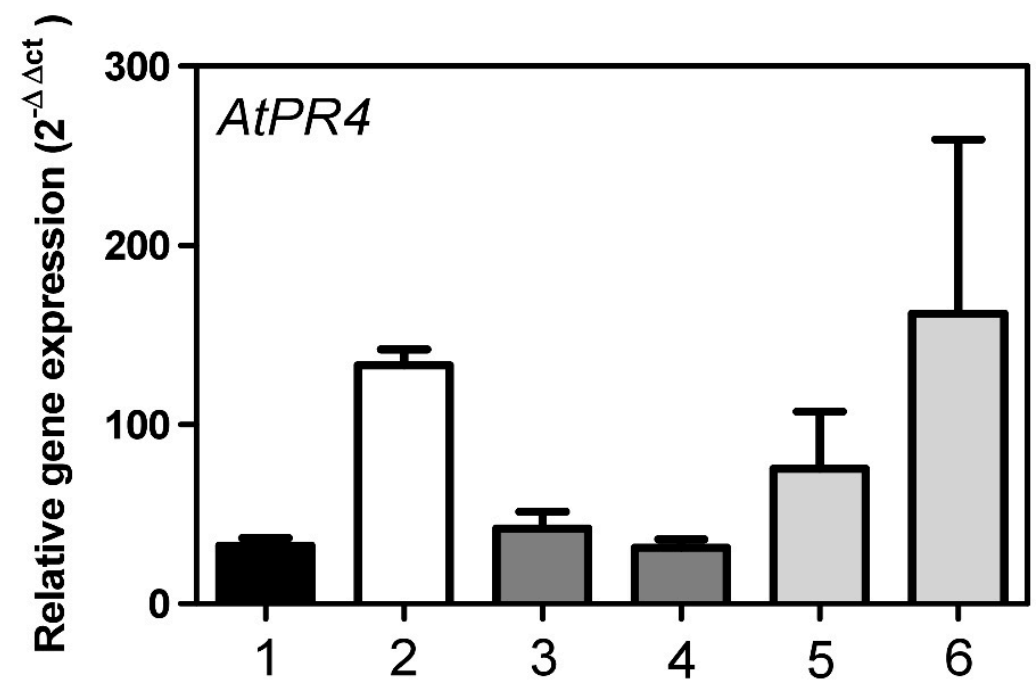

Figure 8. Expression of AtPR4 in A. thaliana leaves under MVK treatment in relation to AtPR4 expression in untreated Ath Col-0 wt. (1) Ath Col-0 wt, (2) AtStR1-, (3) 35S:AtStR1/AtStR1-1, (4) 35S:AtStR1/AtStR1-2, (5) 35S:AtStR2/AtStR1-1, (6) 35S:AtStR2/AtStR1-2. Mean \pm STD ( $=3$, normalized on $A c t 2$ and $E F 1 \alpha\left({ }^{*}=p<0.05\right)$.

AtStR1- mutant plants show a phenotype with altered vein patterning [5]. This phenotype could also be verified in the plants used in this study (Figure 9).
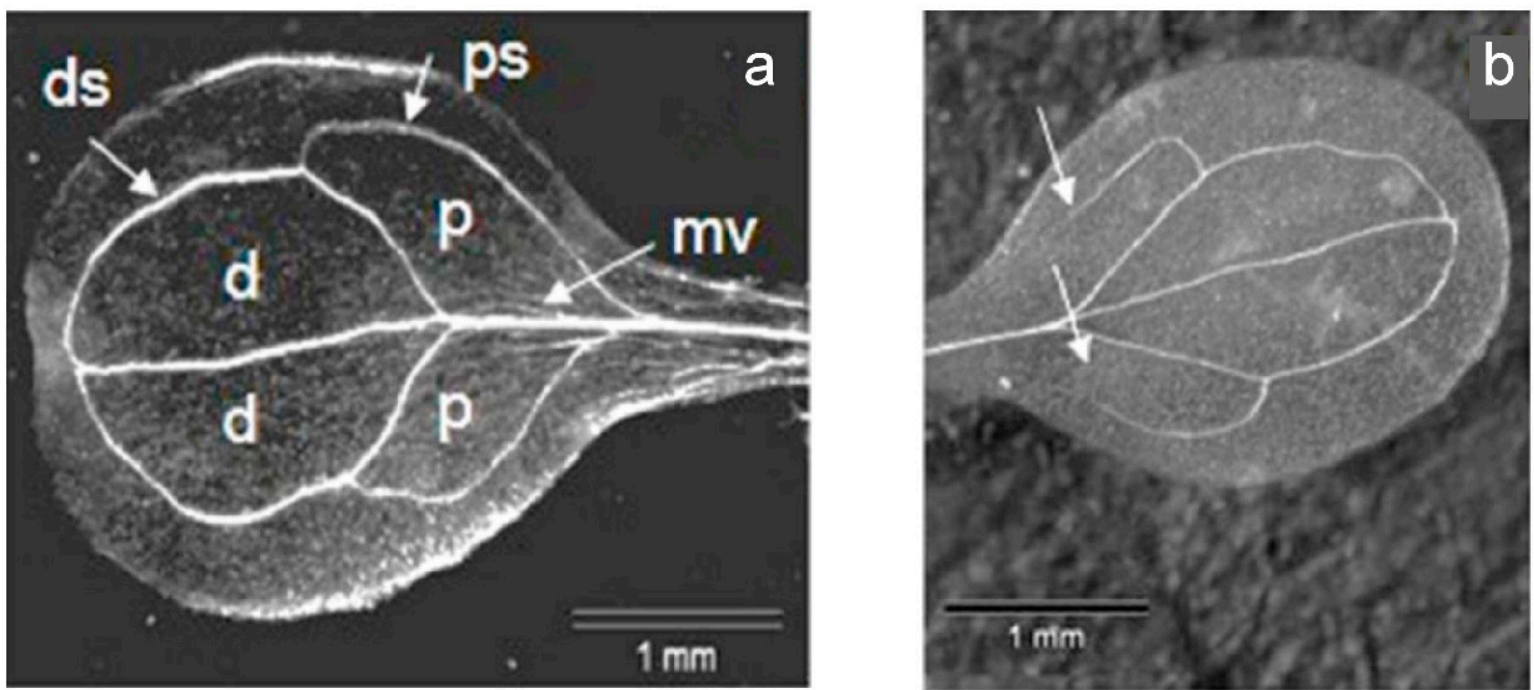

Figure 9. Vein patterning in cotyledons. (a) normal structure with distal (d) and proximal (p) areoles closed; (b) aberrant structure, with only the distal areoles closed. ps = proximal secondary vein; $\mathrm{ds}=$ distal secondary vein; $\mathrm{mv}=$ middle vein. Ath Col-0 wt $(n=217$ seedlings) had $27.6 \%$ ( $8.8 \%$ pairs $)$ and AtStR1- mutant ( $n=208$ seedlings) had $42.3 \%$ (31.7\% pairs) aberrant vein patterning, including the typical aberration shown in (b). 
The expression of the auxin transporter PIN1 is dependent on the availability of GSH, i.e., influenced by the tissue's redox state. PIN1-deficient mutants also showed aberrant vein patterning [42]. We here demonstrated that PIN1 expression was reduced by MVK to less than $30 \%$ of the control values after $3 \mathrm{~h}$ of treatment. PIN1 expression was almost switched off after prolonged MVK treatment. In AtStR1- mutant plants, PIN1 expression levels were about 50\% of the Ath Col-0 wt level. Curing the AtStR1- mutant with 35S:AtStR1 yielded plants showing equally high PIN1 expression as Ath Col-0 wt, whereas recovery was not observed in plants overexpressing 35S:AtStR2 (Figure 10).

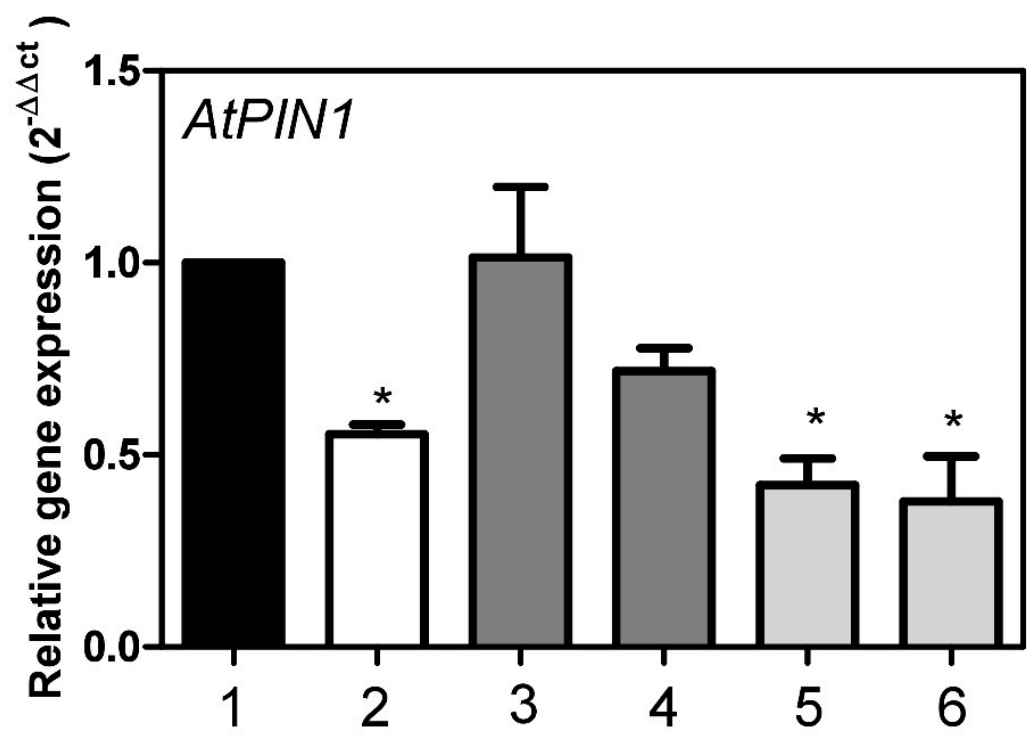

Figure 10. Expression of PIN1 in A. thaliana Col-0 wt and mutant lines. (1) Ath Col-0 wt, (2) AtStR1- mutant, (3) 35S:AtStR1/AtStR1-1, (4) 35S:AtStR1/AtStR1-2, (5) 35S:AtStR2/AtStR1-1, (6) 35S:AtStR2/AtStR1-2. Mean $\pm \operatorname{STD}(n=3)$, normalized on Act2 and EF1 $\alpha\left({ }^{*}=p<0.05\right)$.

All Ath Col-0 wt plants germinated in the presence of MVK $(n=60)$ displayed aberrations in vein patterning, whereas $50 \%$ of the cotyledons of non-treated controls looked like the one shown in Figure 9a. This might be in direct correlation with the reduced PIN1 expression (about 70\%) in MVK treated Ath Col-0 wt plants.

AtStR1- mutant overexpressing 35S:AtStR1 or 35S:AtStR2 could not cure aberrant vein patterning (Figure S5). This may be due to the CaMV 35S promoter which constitutively expresses genes in all transformed tissues. The venation network in Arabidopsis leaves develops in a multistage process, which requires a sophisticated pattern of auxin transport through the leaf tissue. We demonstrated that the process is to some degree perturbed in the absence of functional VEP1 and it seems likely that proper venation network development requires a proper spatiotemporal regulation of VEP1 expression. This may explain why with restored global PIN1 expression levels, constitutive overexpression of VEP1 in our transgenic plants still does not sufficiently mimic the required pattern of VEP1 activity necessary to rescue the phenotype.

This implies that the role of VEP1 in vein patterning is related to the ability of the encoded PRISE (AtStR1) to reduce small reactive 1,4-enones, as demonstrated here for MVK released in stress reactions. Other PRISEs, like AtStR2 in this study, may play completely different roles considering their individual expression patterns, their inability to cure symptoms caused by AtStR1 deficiency and their different substrate specificities with a tendency to discriminate for larger molecules. RES are cytotoxic substances causing cell damage $[20,38]$. RES have also been demonstrated to activate defense-related gene expression and to be involved in signaling pathways ([21,43,44] among others). RES may therefore be regarded as archaic plant signals acting in a phytohormone-like manner. We here demonstrated that AtStR1 gene knockout led to stronger responses of defense-related 
genes after exposure to MVK (Figure 8). We assume that PRISE-independent modulators of defense-related gene expression have evolved in plants.

In correlation with comparative metabolism and the evolution of specialized natural products, PRISEs encoded by VEP1-like genes may facilitate pathways leading to SNAPs [1] such as 5 $\beta$-cardenolides [14] and iridoids [7]. Similarly, BAHD acyltransferases and aromatic prenyltransferases, involved in the biosynthesis of paclitaxel and monoterpenes, respectively, showed an expansion and high rates of evolution favoring some plant-specialized metabolic processes [45]. This might also be the case for the PRISE family in individual plant species.

Enzymes engaged in basic metabolism can be recruited into specialized metabolism in different plant lineages, their substrate promiscuity allowing these enzymes to contribute catalytic steps to new pathways if acceptable substrates are present. Promiscuous enzymes are important elements in pathway evolution and may complement other mechanisms such as changes in transcriptional regulation, defense strategies, changes in protein-protein interactions or protein folding [46].

\section{Materials and Methods}

\subsection{Plant Material}

An AtStR1 T-DNA-insertion line (SALK 097798) was used to investigate the effects of AtStR1 knockout. Plants derived from ordered seeds (Nottingham Arabidopsis Stock Centre; NASC) were tested for homozygous T-DNA insertion by $\mathrm{PCR}\left(\mathrm{T}_{\mathrm{A}}=50^{\circ} \mathrm{C}\right)$. Primers were derived by the online-tool "SALK T-DNA verification primer design" (http:/ / signal. salk.edu/tdnaprimers.2.html (accessed on 17 April 2017); LBp1.3 ATT TTG CCG ATT TCG GAA C; LP097798 TTA TCG CCG TAA CCA CTT TTG; RP097798: AAA CAA CAA CGG AGA CCC TTC). Seeds from homozygous plants were stratified, germinated and cultivated as wild type (wt) plants in the greenhouse. Coding sequence of AtStR1 (At2g24220) or AtStR2 (At5g58750), respectively, was amplified using primers: JK_pEG ${ }^{100}$ _StR1_for: TAT

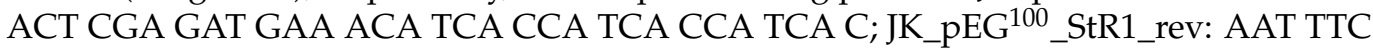

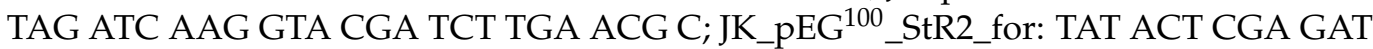
GGG GTC TGA AAA TGG CAG; JK_pEG ${ }^{100} \_$StR2_rev: AAT TTC TAG ATT ACA AAG GAA TGA GTT TTT CAT CT. AtStR1 and AtStR2 coding sequences were then cloned into pEarleyGate $100\left(\mathrm{pEG}^{100}\right)$ using restriction enzymes XhoI and XbaI (New England Biolabs, Ipswich, MA, USA) and transformed into E. coli DH5 $\alpha$ cells. Plasmids isolated from these cells were sequenced and those with verified constructs were used for the transformation of the Agrobacterium tumefaciens strain GV3101 (GV).

Transformed GVs carrying the cloned constructs were used for the transformation of SALK_097798 by floral-dip transformation [47]. Seeds of dipped plants were stratified and germinated as described above. One week after transfer into a climate chamber for germination, the seedlings were treated with glufosinate-ammonium $\left(1 \mathrm{~g} \mathrm{~L}^{-1}\right)$. This was repeated 3 times within 10 days. Surviving plants were tested for the integration of T-DNA by PCR with primers against bar gene (BAR for: TGC ACC ATC GTC AAC CAC TAC ATC GAG; BAR rev: CAG GCT GAA GTC CAG CTG). Plants with integrated T-DNA were transferred into the greenhouse for propagation. Seeds of these plants were stratified, germinated and cultivated as described above. All plants were tested for the integration of T-DNA before their use in experiments.

\subsection{Heterologous Expression of AtStR2}

In the restriction-free cloning of AtStR2 (At5g58750) into expression vector pDEST17, the following primer pairs were used: forward primer: 5'TCGTACTACCATCACCATCACCATCACATGGGGTCTGAAAATGGCA'3. reverse primer: 5'GCCCCAAGGGGTTATGCTAGTTATTACAAAGGAATGAGTTTTTCATCT '3.

Primer pairs were derived using rf-cloning.org [48]. The rf-cloning method [48] had successfully been used for integrating PRISEs into pDEST17 before by [14]. The restrictionfree cloning strategy followed the procedures described previously [14,49] using E. coli 
$\mathrm{DH} 5 \alpha$ cells for the primary transformation and E. coli soluBL21 for the recombinant protein expression. Correctly integrated coding sequence (in frame with His-Tag of pDEST17 vector) was confirmed by sequencing (Eurofins, Brussels, Belgium) using standard primers against T7 promoter and T7 terminator. AtStR2 expression was induced in 1 L E. coli soluBL21 cultures (optical density of 0.5 to 0.7 ) by adding IPTG (final concentration of $0.1 \mathrm{mM}$ ). To avoid inclusion bodies [50] the culture was incubated at $4^{\circ} \mathrm{C}$ for $96 \mathrm{~h}$ as described [13]. This was previously used for the expression of PRISEs [7]. Cells were harvested and protein was extracted as described before [14]. An ÄKTA purifier chromatography system (GE Healthcare, Upsala, Sweden) and HisTrap ${ }^{\mathrm{TM}} \mathrm{HP}$ columns were used for the purification of recombinant AtStR2 by immobilized metal-chelate chromatography, as described by [14]. SDS-PAGE and semidry immunoblotting (Figure S1) were carried out following QIAexpress Detection and Assay Handbook (QIAgen), which was used successfully for PRISEs by [7]. We used 12\% Bis-Tris polyacrylamide gels for SDS-PAGEs and nitrocellulose membranes for electroblotting. Recombinant AtStR2 was detected using mouse anti-His (mixture of RGS-, Tetra-, and Penta-His antibodies; dilution 1:2000; QiAgen, Hilden, Germany) and anti-mouse IgG-peroxidase antibodies (Sigma, Munich, Germany). As a result, we detected recombinant AtStR2 as the chemiluminescence of 3-aminophtalate released from luminol.

\subsection{Enzyme Kinetics}

The reductase activity of recombinant AtStR2 was measured spectrophotometrically by following the conversion of $\mathrm{NADPH} / \mathrm{H}^{+}$at $340 \mathrm{~nm}[7,14,32]$. Enzyme kinetics were determined by using protein concentrations from 0.01 to $0.1 \mathrm{mg} / \mathrm{mL}$ of recombinant AtStR2 (depending on the substrate analyzed), $0.2 \mathrm{mM} \mathrm{NADPH} / \mathrm{H}^{+}$and varying concentrations of the different substrates (0.05 to $1.6 \mathrm{mM})$ [14].

\subsection{In Silico Analysis}

The sequence alignment was generated using ClustalW [22]. The homology model of AtStR2 was built on the crystal structure of AtStR1 (Schmidt et al. 2018, PDB entry 6el3.1.A) with Swissmodel [29]. Docking simulations of progesterone were performed with AutoDock Vina [30]. The search area for appropriate docking was defined as a cube (side length $=30 \AA)$, the coordinates $(5 /-5 /-60)$ were optimized manually. UCSF Chimera [31] was used to visualize the docking calculations.

\subsection{MVK Stress Treatment}

A total of $16 \mu \mathrm{L}$ of a MVK solution (Merck KGaA, Darmstadt, Germany) was diluted with $50 \mathrm{~mL}$ of water. Plants were transferred into a $1 \mathrm{~L}$ gas chamber. Diluted MVK was added to a total concentration of $2 \mu \mathrm{mol} \mathrm{L}{ }^{-1}$ air volume and the chamber sealed during a $3 \mathrm{~h}$ incubation. Control plants were treated with tap water. Plant material was harvested after a 3 h treatment [14].

\subsection{Cold Treatment}

For cold treatment, plants were transferred into a climate chamber at $4{ }^{\circ} \mathrm{C}$ and treated for $36 \mathrm{~h}$ under long day conditions ( $16 \mathrm{~h}$ light $/ 8 \mathrm{~h}$ dark). Control plants were cultivated in a climate chamber at $22{ }^{\circ} \mathrm{C}$ under long day conditions (16 h light $/ 8 \mathrm{~h}$ dark). mRNA values of AtStR1, AtStR2 and AtAct2 were shown on agarose gels of both control and stressed plants (Figure S3). Primers used in this experiment are presented in a data supplement (Supplementary Table S2).

\subsection{RNA Isolation and $c D N A-S y n t h e s i s$}

For RNA isolation, the 4 youngest leaves and the shoot apical meristem or 7 days old seedlings were used. Isolation was done with the use of Monarch ${ }^{\circledR}$ Total RNA Miniprep Kit (New England Biolabs, Ipswich, MA, USA). gDNA was digested with a DNase I (New England Biolabs, Ipswich, USA) treatment. A total of $1500 \mu \mathrm{g}$ of the resulting RNA was transcribed into cDNA by using a RevertAid H Minus First Strand cDNA Synthesis Kit 
(Thermo Fisher Scientific Inc., Waltham, MA, USA). cDNA was diluted 3:1 and used for quantitative real-time PCR.

\subsection{Quantitative Real-Time PCR and Semiquantitative PCR}

All quantitative real-time PCRs (qPCR) were realized in a Rotor-Gene $\mathrm{Q}$ thermocycler (Qiagen, Venlo, The Netherlands) using the following program $\left(180 \mathrm{~s}\right.$ at $95^{\circ} \mathrm{C}$ followed by 40 cycles of $15 \mathrm{~s}$ at $95^{\circ} \mathrm{C} ; \mathrm{T}_{\mathrm{A}} 40 \mathrm{~s}$ ) and Brilliant III Ultra-Fast SYBR ${ }^{\circledR}$ Green QPCR Master Mix (Agilent Technologies, Santa Clara, CA, USA). Quantification of gene expression was calculated using the $2^{-\Delta \Delta c t}$-method [51]. Primers designed for quantitative real-time PCR are listed in a data supplement (Supplementary Table S1). Semiquantitative PCR was carried out in a peqSTAR 96 Universal Gradient thermocycler (Peqlab, Erlangen, Germany) using either primers shown in Supplementary Table S1 and a mRNA template isolated from adult leaves and seedlings, or primers shown in Supplementary Table S2 and an mRNA template extracted from adult leaves after cold treatment. The PCR program was designed as follows: $1 \times 95^{\circ} \mathrm{C}$ for $180 \mathrm{~s}, 40$ cycles, $95^{\circ} \mathrm{C}$ for $20 \mathrm{~s}, 50{ }^{\circ} \mathrm{C}$ for $30 \mathrm{~s}, 68^{\circ} \mathrm{C}$ for $60 \mathrm{~s}, 1 \times 68^{\circ} \mathrm{C}$ for $600 \mathrm{~s}$. Taq DNA Polymerase (New England Biolabs, Ipswich, MA, USA) was used for semiquantitative PCR. PCR products were separated on $1 \%$ agarose gels.

\subsection{Quantification of Protein Activity in Plant Extracts}

One gram of fresh leaves was snap frozen in liquid nitrogen. Frozen plant material was ground to a fine powder. To a total of $0.2 \mathrm{~g}$ of plant material the same amount of PVPP was added. Protein extraction from plant material followed the method of [52].

Total protein concentrations were determined according to [53]. Progesterone $5 \beta$-reductase activity was assayed in the presence of $1 \mathrm{mg} \mathrm{mL}^{-1}$ total leaf protein, $0.3 \mathrm{mM}$ progesterone and a NADPH/ $\mathrm{H}^{+}$-regenerating system (1.1 mM glucose 6-phosphate, $6.4 \mathrm{mM} \mathrm{NADP}+$ and 4.2 nkat glucose-6-phosphate dehydrogenase) as described by [14,52]. To monitor the consumption of substrate we used a Shimadzu GC2010/QP-2010S in IE mode with helium as carrier gas (flow: $1.2 \mathrm{~mL} \mathrm{~min}{ }^{-1}$ ) and DB-5ms columns (JW GC column) from Agilent $(30 \mathrm{~m} \times 0.25 \mathrm{~mm} \times 0.25 \mu \mathrm{m})$. Progesterone and testosterone (internal standard) were from Steraloids Inc. (Newport, RI, USA). The program used is described by [14]. Additionally, products of the above-mentioned enzyme assays were blotted on TLC plates (silica gel 60; Merck) and run in GC-MS analysis (Figure S4), as described by [53].

\subsection{Analysis of the Vein Patterning in Cotyledons}

Plant tissue was fixed by immersion in a mixture of ethanol and acetic acid (3:1) overnight to remove chlorophyll and subsequently washed with water. The vein patterning was analyzed with an Axioskop HBO 50 (Zeiss).

\subsection{Statistical Analysis}

Experiments were conducted as three or more independent biological replicates with three technical replicates each. One-way analyses of variance (ANOVA followed by Tukey's post hoc test) were used to compare the means of various groups. A post hoc Bonferroni correction was applied for multiple comparisons. $p$ values $\leq 0.05$ were considered as statistically significant and indicated by an asterisk. GraphPad Prism 8 Software (GraphPad) was used for data analysis and graph design.

\section{Conclusions}

Our results added evidence that AtStR1, AtStR2 and PRISEs of different clusters in general play different roles in stress and defense mechanisms. Based on our findings, we conclude that PRISEs are involved in the detoxification of small reactive 1,4-enones and are therefore part of the complex detoxification machinery of RES in plants. In the context of comparative metabolism and the evolution of specialized natural products (SNAPs), promiscuous enzymes, such as PRISEs, can provide important elements in pathway evolution. A comparison of closely related plant species, accumulating different sets of SNAPs 
but sharing homologues sets of genes/enzymes, adds a valuable new way of looking at comparative metabolism and "silent" or "underground" metabolism.

Supplementary Materials: The following are available online at https://www.mdpi.com/article/10.3390/ metabo12010011/s1, Figure S1: SDS-PAGE and Western blot of rAtStR2, Figure S2: Enantioselective conversion of progesterone by r $A t S t R 2$, Figure S3: Expression of AtStR1 and AtStR2 after cold shock treatment, Figure S4: Analysis of progesterone $5 \beta$-reductase activity assayed in plant leaf extracts of $A$ th $\mathrm{Col}-0 \mathrm{wt}$ and mutant lines, Figure S5: Analysis of vein patterning in Ath Col- $0 \mathrm{wt}$ and mutant lines, Table S1: List of primer pairs for quantitative real-time PCR experiments, Table S2: List of primers used in cold treatment experiment.

Author Contributions: Conceptualization, W.K., J.K. and J.M.; investigation, J.K., M.E., A.C., M.T., T.L. and J.M.; writing-original draft preparation, J.K., W.K. and J.M.; writing-review and editing, W.K., A.C. and J.M. All authors have read and agreed to the published version of the manuscript.

Funding: This research received no external funding.

Institutional Review Board Statement: Not applicable.

Informed Consent Statement: Not applicable.

Data Availability Statement: Data is contained within the article or supplementary material.

Acknowledgments: We thank Maria Netfidou and Benedikt Kost (Cell Biology, FAU) for providing vector pFAU27, Angelika Wolf for guidance during plant transformation experiments, Anastasiia Ignatova for lab assistance, Ruth Stadler (Molecular Plant Physiology, FAU) for helpful discussion and Barbara White for linguistic advice.

Conflicts of Interest: The authors declare no conflict of interest.

\section{References}

1. Kreis, W.; Munkert, J. Exploiting enzyme promiscuity to shape plant specialized metabolism. J. Exp. Bot. 2019, 70, 1435-1445. [CrossRef] [PubMed]

2. Noda-Garcia, L.; Liebermeister, W.; Tawfik, D.S. Metabolite-Enzyme Coevolution: From Single Enzymes to Metabolic Pathways and Networks. Annu. Rev. Biochem. 2018, 87, 187-216. [CrossRef]

3. Djoumbou-Feunang, Y.; Fiamoncini, J.; Gil-de-la-Fuente, A.; Greiner, R.; Manach, C.; Wishart, D.S. BioTransformer: A comprehensive computational tool for small molecule metabolism prediction and metabolite identification. J. Cheminform. 2019, 11, 2. [CrossRef]

4. EFSA Workshop on in vitro comparative metabolism studies in regulatory pesticide risk assessment. EFSA Support. Publ. 2019, 16, 1618E. [CrossRef]

5. Jun, J.H.; Ha, C.M.; Nam, H.G. Involvement of the VEP1 gene in vascular strand development in Arabidopsis thaliana. Plant Cell Physiol. 2002, 43, 323-330. [CrossRef] [PubMed]

6. Yang, K.Y.; Moon, Y.H.; Choi, K.H.; Kim, Y.H.; Eun, M.Y.; Guh, J.O.; Kim, K.C.; Cho, B.H. Structure and expression of the AWI 31 gene specifically induced by wounding in Arabidopsis thaliana. Mol. Cells 1997, 7, 131-135. [PubMed]

7. Munkert, J.; Pollier, J.; Miettinen, K.; van Moerkercke, A.; Payne, R.; Müller-Uri, F.; Burlat, V.; O'Connor, S.E.; Memelink, J.; Kreis, W.; et al. Iridoid synthase activity is common among the plant progesterone $5 \beta$-reductase family. Mol. Plant 2015, 8, 136-152. [CrossRef]

8. Herl, V.; Fischer, G.; Reva, V.A.; Stiebritz, M.; Muller, Y.A.; Müller-Uri, F.; Kreis, W. The VEP1 gene (At4g24220) encodes a short-chain dehydrogenase/reductase with 3-oxo-Delta4,5-steroid 5beta-reductase activity in Arabidopsis thaliana L. Biochimie 2009, 91, 517-525. [CrossRef]

9. Schmidt, K.; Petersen, J.; Munkert, J.; Egerer-Sieber, C.; Hornig, M.; Muller, Y.A.; Kreis, W. PRISEs (progesterone $5 \beta$-reductase and/or iridoid synthase-like 1,4-enone reductases): Catalytic and substrate promiscuity allows for realization of multiple pathways in plant metabolism. Phytochemistry 2018, 156, 9-19. [CrossRef]

10. Petersen, J.; Lanig, H.; Munkert, J.; Bauer, P.; Müller-Uri, F.; Kreis, W. Progesterone $5 \beta$-reductases/iridoid synthases (PRISE) Gatekeeper role of highly conserved phenylalanines in substrate preference and trapping is supported by molecular dynamics simulations. J. Biomol. Struct. Dyn. 2016, 34, 1667-1680. [CrossRef]

11. Gärtner, D.E.; Keilholz, W.; Seitz, H.U. Purification, characterization and partial peptide microsequencing of progesterone 5 beta-reductase from shoot cultures of Digitalis purpurea. Eur. J. Biochem. 1994, 225, 1125-1132. [CrossRef] [PubMed]

12. Roca-Pérez, L.; Boluda, R.; Gavidia, I.; Pérez-Bermúdez, P. Seasonal cardenolide production and Dop $5 \beta r$ gene expression in natural populations of Digitalis obscura. Phytochemistry 2004, 65, 1869-1878. [CrossRef]

13. Herl, V.; Fischer, G.; Mueller-Uri, F.; Kreis, W. Molecular cloning and heterologous expression of progesterone $5 \beta$-reductase from Digitalis lanata Ehrh. Phytochemistry 2006, 67, 225-231, Erratum in Phytochemistry 2008, 69, 2411. [CrossRef] [PubMed] 
14. Klein, J.; Horn, E.; Ernst, M.; Leykauf, T.; Leupold, T.; Dorfner, M.; Wolf, L.; Ignatova, A.; Kreis, W.; Munkert, J. RNAimediated gene knockdown of progesterone $5 \beta$-reductases in Digitalis lanata reduces $5 \beta$-cardenolide content. Plant Cell Rep. 2021, 40, 1631-1646. [CrossRef] [PubMed]

15. Geu-Flores, F.; Sherden, N.H.; Courdavault, V.; Burlat, V.; Glenn, W.S.; Wu, C.; Nims, E.; Cui, Y.; O'Connor, S.E. An alternative route to cyclic terpenes by reductive cyclization in iridoid biosynthesis. Nature 2012, 492, 138-142. [CrossRef]

16. Nguyen, T.-D.; O'Connor, S.E. The Progesterone 5 $\beta$-Reductase/Iridoid Synthase Family: A Catalytic Reservoir for Specialized Metabolism across Land Plants. ACS Chem. Biol. 2020, 15, 1780-1787. [CrossRef]

17. Tarrío, R.; Ayala, F.J.; Rodríguez-Trelles, F. The Vein Patterning 1 (VEP1) gene family laterally spread through an ecological network. PLoS ONE 2011, 6, e22279. [CrossRef]

18. Burda, E.; Kraußer, M.; Fischer, G.; Hummel, W.; Müller-Uri, F.; Kreis, W.; Gröger, H. Recombinant $\Delta 4,5$-Steroid $5 \beta$-Reductases as Biocatalysts for the Reduction of Activated C=C-Double Bonds in Monocyclic and Acyclic Molecules. Adv. Synth. Catal. 2009, 351, 2787-2790. [CrossRef]

19. Durchschein, K.; Wallner, S.; Macheroux, P.; Schwab, W.; Winkler, T.; Kreis, W.; Faber, K. Nicotinamide-Dependent Ene Reductases as Alternative Biocatalysts for the Reduction of Activated Alkenes. Eur. J. Org. Chem. 2012, 2012, 4963-4968. [CrossRef]

20. Kai, H.; Hirashima, K.; Matsuda, O.; Ikegami, H.; Winkelmann, T.; Nakahara, T.; Iba, K. Thermotolerant cyclamen with reduced acrolein and methyl vinyl ketone. J. Exp. Bot. 2012, 63, 4143-4150. [CrossRef]

21. Alméras, E.; Stolz, S.; Vollenweider, S.; Reymond, P.; Mène-Saffrané, L.; Farmer, E.E. Reactive electrophile species activate defense gene expression in Arabidopsis. Plant J. 2003, 34, 205-216. [CrossRef] [PubMed]

22. Madeira, F.; Park, Y.M.; Lee, J.; Buso, N.; Gur, T.; Madhusoodanan, N.; Basutkar, P.; Tivey, A.R.N.; Potter, S.C.; Finn, R.D.; et al The EMBL-EBI search and sequence analysis tools APIs in 2019. Nucleic Acids Res. 2019, 47, W636-W641. [CrossRef] [PubMed]

23. Thorn, A.; Egerer-Sieber, C.; Jäger, C.M.; Herl, V.; Müller-Uri, F.; Kreis, W.; Muller, Y.A. The crystal structure of progesterone $5 \beta$-reductase from Digitalis lanata defines a novel class of short chain dehydrogenases/reductases. J. Biol. Chem. 2008, 283, 17260-17269. [CrossRef] [PubMed]

24. Pérez-Bermúdez, P.; García, A.A.M.; Tuñón, I.; Gavidia, I. Digitalis purpurea P5 $\beta R 2$, encoding steroid $5 \beta$-reductase, is a novel defense-related gene involved in cardenolide biosynthesis. New Phytol. 2010, 185, 687-700. [CrossRef] [PubMed]

25. Rieck, C.; Geiger, D.; Munkert, J.; Messerschmidt, K.; Petersen, J.; Strasser, J.; Meitinger, N.; Kreis, W. Biosynthetic approach to combine the first steps of cardenolide formation in Saccharomyces cerevisiae. Microbiologyopen 2019, 8, e925. [CrossRef]

26. Mano, J.; Torii, Y.; Hayashi, S.; Takimoto, K.; Matsui, K.; Nakamura, K.; Inzé, D.; Babiychuk, E.; Kushnir, S.; Asada, K. The NADPH:quinone oxidoreductase P1- $\zeta$-crystallin in Arabidopsis catalyzes the $\alpha, \beta$-hydrogenation of 2-alkenals: Detoxication of the lipid peroxide-derived reactive aldehydes. Plant Cell Physiol. 2002, 43, 1445-1455. [CrossRef]

27. Yamauchi, Y.; Hasegawa, A.; Taninaka, A.; Mizutani, M.; Sugimoto, Y. NADPH-dependent reductases involved in the detoxification of reactive carbonyls in plants. J. Biol. Chem. 2011, 286, 6999-7009. [CrossRef]

28. Berman, H.M.; Westbrook, J.; Feng, Z.; Gilliland, G.; Bhat, T.N.; Weissig, H.; Shindyalov, I.N.; Bourne, P.E. The Protein Data Bank. Nucleic Acids Res. 2000, 28, 235-242. [CrossRef]

29. Waterhouse, A.; Bertoni, M.; Bienert, S.; Studer, G.; Tauriello, G.; Gumienny, R.; Heer, F.T.; de Beer, T.A.P.; Rempfer, C.; Bordoli, L.; et al. SWISS-MODEL: Homology modelling of protein structures and complexes. Nucleic Acids Res. 2018, 46, W296W303. [CrossRef] [PubMed]

30. Trott, O.; Olson, A.J. AutoDock Vina: Improving the speed and accuracy of docking with a new scoring function, efficient optimization, and multithreading. J. Comput. Chem. 2010, 31, 455-461. [CrossRef]

31. Pettersen, E.F.; Goddard, T.D.; Huang, C.C.; Couch, G.S.; Greenblatt, D.M.; Meng, E.C.; Ferrin, T.E. UCSF Chimera-A visualization system for exploratory research and analysis. J. Comput. Chem. 2004, 25, 1605-1612. [CrossRef]

32. Bauer, P.; Munkert, J.; Brydziun, M.; Burda, E.; Müller-Uri, F.; Gröger, H.; Muller, Y.A.; Kreis, W. Highly conserved progesterone $5 \beta$-reductase genes (P5 $\beta R$ ) from 5 beta-cardenolide-free and $5 \beta$-cardenolide-producing angiosperms. Phytochemistry 2010, 71, 1495-1505. [CrossRef]

33. Tropper, M.; Höhn, S.; Wolf, L.-S.; Fritsch, J.; Kastner-Detter, N.; Rieck, C.; Munkert, J.; Meitinger, N.; Lanig, H.; Kreis, W. 21-Hydroxypregnane 21-O-malonylation, a crucial step in cardenolide biosynthesis, can be achieved by substrate-promiscuous BAHD-type phenolic glucoside malonyltransferases from Arabidopsis thaliana and homolog proteins from Digitalis lanata. Phytochemistry 2021, 187, 112710. [CrossRef] [PubMed]

34. Yin, L.; Mano, J.; Tanaka, K.; Wang, S.; Zhang, M.; Deng, X.; Zhang, S. High level of reduced glutathione contributes to detoxification of lipid peroxide-derived reactive carbonyl species in transgenic Arabidopsis overexpressing glutathione reductase under aluminum stress. Physiol. Plant. 2017, 161, 211-223. [CrossRef] [PubMed]

35. Lewinsohn, E.; Gijzen, M. Phytochemical diversity: The sounds of silent metabolism. Plant Sci. 2009, 176, 161-169. [CrossRef]

36. Jardine, K.J.; Meyers, K.; Abrell, L.; Alves, E.G.; Serrano, A.M.Y.; Kesselmeier, J.; Karl, T.; Guenther, A.; Chambers, J.Q.; Vickers, C. Emissions of putative isoprene oxidation products from mango branches under abiotic stress. J. Exp. Bot. 2013, 64, 3697-3708. [CrossRef] [PubMed]

37. Cappellin, L.; Loreto, F.; Biasioli, F.; Pastore, P.; McKinney, K. A mechanism for biogenic production and emission of MEK from MVK decoupled from isoprene biosynthesis. Atmos. Chem. Phys. 2019, 19, 3125-3135. [CrossRef]

38. Vollenweider, S.; Weber, H.; Stolz, S.; Chételat, A.; Farmer, E.E. Fatty acid ketodienes and fatty acid ketotrienes: Michael addition acceptors that accumulate in wounded and diseased Arabidopsis leaves. Plant J. 2000, 24, 467-476. [CrossRef] 
39. Horiyama, S.; Hatai, M.; Ichikawa, A.; Yoshikawa, N.; Nakamura, K.; Kunitomo, M. Detoxification Mechanism of $\alpha$, $\beta$-Unsaturated Carbonyl Compounds in Cigarette Smoke Observed in Sheep Erythrocytes. Chem. Pharm. Bull. 2018, 66, 721-726. [CrossRef]

40. Ernst, M. Untersuchungen zur physiologischen Funktion der Progesteron-5 $\beta$-Reduktase in Arabidopsis thaliana und Vitis vinifera. Ph.D. Thesis, Friedrich-Alexander-Universität Erlangen-Nürnberg (FAU), Erlangen, Germany, 2015.

41. Harvey, C.M.; Sharkey, T.D. Exogenous isoprene modulates gene expression in unstressed Arabidopsis thaliana plants. Plant Cell Environ. 2016, 39, 1251-1263. [CrossRef]

42. Bashandy, T.; Guilleminot, J.; Vernoux, T.; Caparros-Ruiz, D.; Ljung, K.; Meyer, Y.; Reichheld, J.-P. Interplay between the NADP-linked thioredoxin and glutathione systems in Arabidopsis auxin signaling. Plant Cell 2010, 22, 376-391. [CrossRef] [PubMed]

43. Biswas, M.S.; Fukaki, H.; Mori, I.C.; Nakahara, K.; Mano, J. Reactive oxygen species and reactive carbonyl species constitute a feed-forward loop in auxin signaling for lateral root formation. Plant J. 2019, 100, 536-548. [CrossRef] [PubMed]

44. Mano, J.; Biswas, M.S.; Sugimoto, K. Reactive Carbonyl Species: A Missing Link in ROS Signaling. Plants 2019, 8, 391. [CrossRef] [PubMed]

45. Kusano, H.; Li, H.; Minami, H.; Kato, Y.; Tabata, H.; Yazaki, K. Evolutionary Developments in Plant Specialized Metabolism, Exemplified by Two Transferase Families. Front. Plant Sci. 2019, 10, 794. [CrossRef]

46. Moghe, G.D.; Last, R.L. Something Old, Something New: Conserved Enzymes and the Evolution of Novelty in Plant Specialized Metabolism. Plant Physiol. 2015, 169, 1512-1523. [CrossRef]

47. Clough, S.J.; Bent, A.F. Floral dip: A simplified method for Agrobacterium-mediated transformation of Arabidopsis thaliana. Plant J. 1998, 16, 735-743. [CrossRef]

48. Bond, S.R.; Naus, C.C. RF-Cloning.org: An online tool for the design of restriction-free cloning projects. Nucleic Acids Res. 2012, 40, W209-W213. [CrossRef]

49. Unger, T.; Jacobovitch, Y.; Dantes, A.; Bernheim, R.; Peleg, Y. Applications of the Restriction Free (RF) cloning procedure for molecular manipulations and protein expression. J. Struct. Biol. 2010, 172, 34-44. [CrossRef]

50. Stevens, R.C. Design of high-throughput methods of protein production for structural biology. Structure 2000, 8, R177-R185. [CrossRef]

51. Livak, K.J.; Schmittgen, T.D. Analysis of relative gene expression data using real-time quantitative $\mathrm{PCR}$ and the $2(-\Delta \Delta C(\mathrm{~T}))$ Method. Methods 2001, 25, 402-408. [CrossRef]

52. Ernst, M.; de Padua, R.M.; Herl, V.; Müller-Uri, F.; Kreis, W. Expression of 3 $\beta$-HSD and P5 $\beta R$, genes respectively coding for $\Delta 5-3 \beta$-hydroxysteroid dehydrogenase and progesterone $5 \beta$-reductase, in leaves and cell cultures of Digitalis lanata EHRH. Planta Med. 2010, 76, 923-927. [CrossRef] [PubMed]

53. Bradford, M.M. A rapid and sensitive method for the quantitation of microgram quantities of protein utilizing the principle of protein-dye binding. Anal. Biochem. 1976, 72, 248-254. [CrossRef] 